해양 미소 편모조류의 종 동정을 위한 인편 형태에 관한 연구

\author{
김형신* · 정민민 ${ }^{1}$ \\ (제주대학교 기초과학연구소 · 1 국립수산과학원 제주수산연구소)
}

\title{
Scale Morphologies for Identification of Marine Nanoflagellates
}

\author{
Hyeung-Sin Kim* and Min-Min Jung1 \\ Research Institute for Basic Science, Jeju National University, Ara-1 Dong, Jeju-Si, Jeju-Do 690-756, Korea \\ ${ }^{1}$ Jeju Fisheries Research Institute, National Fisheries Research and Development Institute(NFRDI), 785, \\ Wimi-ri, Namwon-up, Namjeju-gun, Jeju-do, 699-800, Korea
}

\begin{abstract}
5 Haptophyta 2 Chrysophyta and 1 Prasinophyta species of scale-bearing nanoflagellates were collected in coastal water of Korea and identified by examination of their scales with Field Emission Scanning Electron Microscope (JSM-6700F). These included Chrysochromulina ahrengoti, C. simplex, C. spinifera, Prymnesium parvum, P. patelliferum, Mamiella gilva, Paraphysomonas imperforata and Pa. vestita. The surface of cells covered with unmineralised scales (5 Haptophyte and 1 Prasinophyta species) or silica scales (2 Chrysophyta species). Scale-covered flagella are found in the 1 Prasinophyta species. One of the main structural characteristics of Haptophyte is the haptonema, a filiform organelle which occurs together with the two flagella. It may be long and coiling upon irritation as in Chrysochromulina, or short and noncoiling as in Prymnesium.
\end{abstract}

Key Words: Haptophyta, Chrysophyta, Prasinophyta, nanoflagellate, scale

서 론

Nanoflagellates(이하 미소 편모조류로 표기)는 식물플랑크 톤 군집 중 숨겨진 분류군(hidden flora)으로 표현되어질 만 큼 그 크기가 2-20 $\mu \mathrm{m}$ 로 매우 작고 채집과 보존 그리고 광학 현미경을 이용한 실험법 등에 관한 표준적인 방법이 제시되 어 있지 않은 것이 사실이다(LeRoi and Hallegraeff 2004). 그 럼에도 불구하고 이들 미소 편모조류는 식물플랑크톤의 주 요 구성요소이며, 생물 총량의 $90 \%$ 이상을 점하며 기초생산 의 50\% 이상을 책임지고 있다(Malone 1980; Hallegraeff 1981). 이처럼 자연 수역에서의 중요한 기능에도 불구하고 이들 미소 편모조류는 그 크기가 작은 이유로 연구의 대상에 서 제외되어 온 것이 사실이다. 왜냐하면 크기가 작아 분류 를 위한 생물종의 특성 관찰이 어려웠던 점이 주요한 원인중 의 하나이다.

*Corresponding author (kimhyeungsin@hanmail.net)
이들 미소 편모조류 중에는 세포 표면이 인편으로 둘러싸 여 있으며 이들 인편의 형태가 생물종 분류를 위한 하나의 기준이 되어지는 편모조류가 있으며 그 종류 또한 다양하다 (Tomas 1997). 그러나 이들 생물종 역시 그 크기가 매우 작 아서 전자현미경을 이용하지 않으면 관찰 및 종 동정이 불가 능한 것이 사실이며 이러한 이유로 우리나라에서도 인편을 가지는 미소 편모조류에 관한 연구가 매우 적은 편이다. 지 금까지 연구되어진 결과를 보면 인편을 가지는 미소 편모조 류는 주로 늪이나 댐 등에 서식하는 담수산 종이며 (Lee et al. 1994 ; 이 등 $1995 \mathrm{a}$; 이 등 $1995 \mathrm{~b})$ 해산종은 소수에 불과하다 (김과 정 2004c).

특히 인편을 가지는 많은 종류의 미소 편모조류들 중에는 적조의 원인이 되는 종과 독성을 가지고 있으면서 다른 수서 생물의 생존을 위협하는 종들도 알려져 있다(Moestrup and Larsen 1992; Moestrup 1994; UNESCO 2003; 김과 정 2005). 이 연구에서는 우리나라 연안 해역에서 주로 채집 되어지 는 식물플랑크톤 중 인편을 가지는 미소 편모조류에 대해 전 자현미경 관찰을 통하여 종의 형태적 특성을 파악하고 이를 

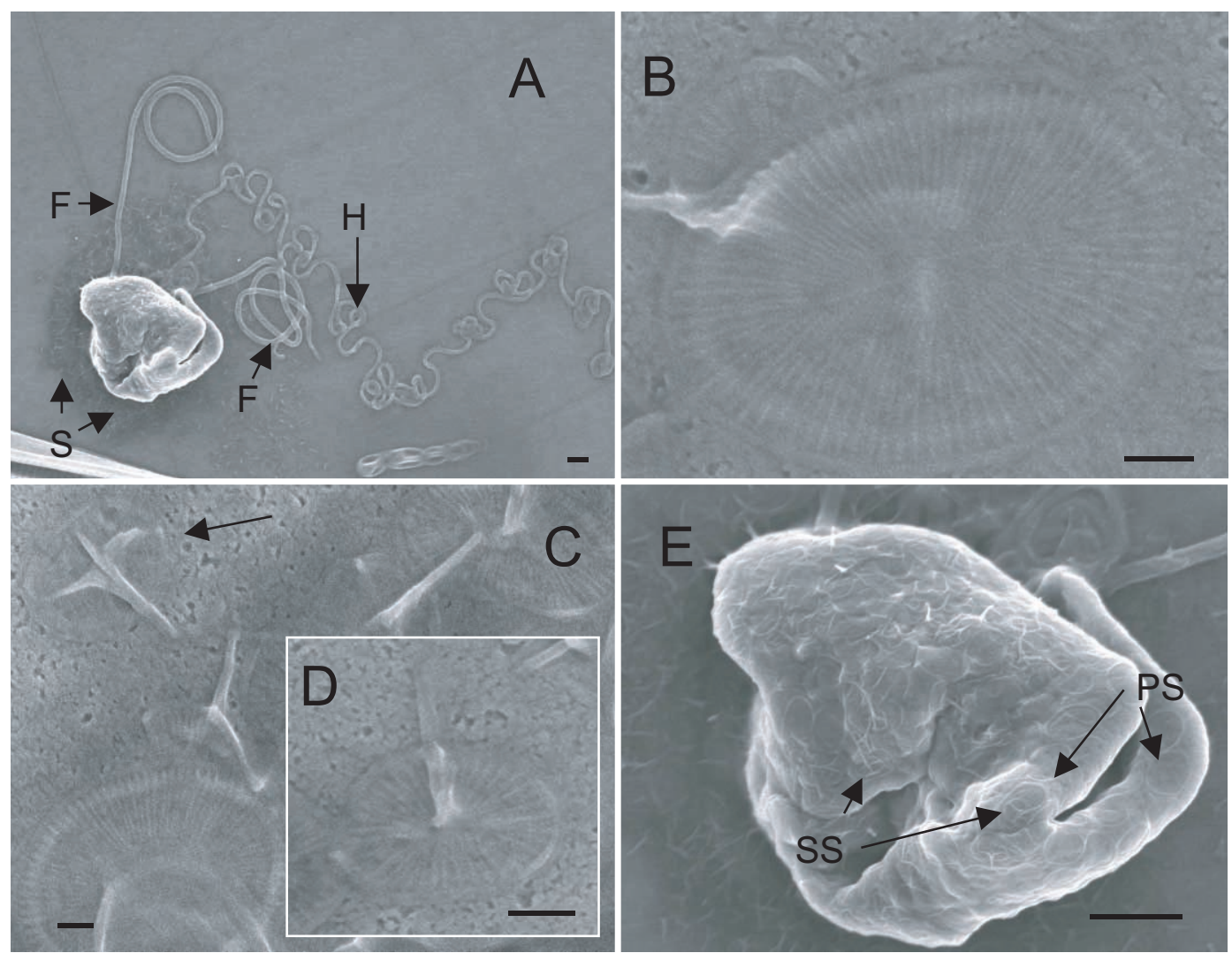

Fig. 1. Chrysochromulina ahrengotii. A. Whole cell with flagella (F), haptonema $(\mathrm{H})$ and detached scales (S), B. Plate scale, C. Spine scale (arrow, distal view), D. Spine scale (proximal view), E. Plate scales (PS) and spine scales (SS) attached on the cell surface. Scale bars $=1 \mu \mathrm{m}(\mathrm{A}, \mathrm{E})$ and $0.1 \mu \mathrm{m}$ (B-D).

바탕으로 종 분류를 행하였다.

\section{재료와 방법}

관찰용 시료는 2002년 10 월부터 2004년 10월까지 제주도를 포함한 우리나라 전 연안 해역에서 채집하였다(김과 정 2004a, b). 특히 이번 전자현미경 관찰에 이용되어진 미소 편 모조류는 동해안의 화진포, 경포호, 서해안의 제부도 연안, 만리포항, 강화대교 인근 연안, 남해안의 부산 영도구 동삼 중리 연안, 마산항, 삼천포, 통영시 사량도, 거제도 장목, 여 수시 만성리, 진도대교 연안 및 제주도의 외도, 서귀포항, 위 미, 성산, 김녕, 함덕, 하귀 연안 등지에서 채집된 시료로부 터 분리하여 이용하였다. 미소 편모조류는 그 크기가 매우 작아 기존의 플랑크톤 넷트를 이용한 채집 방법으로는 시료 채집이 불가능하므로 채수방법을 통해 시료를 확보하였다. 2 $\mathrm{L}$ 멸균 채수통에 연안의 해수를 채수하여 실험실로 운반하 였다. 시료는 온도 $20^{\circ} \mathrm{C}$, 조도 $1,540 \mathrm{~lx}$, 광조건 $12 \mathrm{~h}$ light- $12 \mathrm{~h}$ dark cycle의 배양실에서 배양, 보관하면서 광학현미경을 이 용하여 미소 편모조류의 유무를 관찰하였다. 관찰된 미소 편 모조류는 각각 분리하여 $\mathrm{f} / 2$ 배지가 담긴 $100 \mathrm{ml}$ 삼각플라스
크에 수용하여 전술한 온도, 조도 및 광조건하에서 배양하였 다. 약 10 일간의 배양 기간을 통해 세포수가 증가하면 전자 현미경 관찰을 통하여 세포 형태와 미세구조를 관찰하였다. 전자현미경 관찰을 위한 시료 제작은 Chang and Ryan (1985)의 방법에 따랐다.

\section{결과와 고찰}

Division HAPTOPHYTA(= Prymnesiophyta)

Class Haptophyceae

Order Prymnesiales

Family Prmnesiaceae

Genus Chrysochromulina

\section{Chrysochromulina ahrengotii M.Ø. Jensen et Moestrup (Fig. 1)}

말 안장 모양을 한 세포와 매우 긴 하나의 착편모 (haptonema) 그리고 2개의 편모로 구성된다(Fig. 1-A). 세 포의 크기는 길이가 $6.0-7.5 \mu \mathrm{m}$, 폭이 5.5-7.0 $\mu \mathrm{m}$ 이며 편모 의 길이는 약 30-32.5 $\mu \mathrm{m}$, 착편모의 길이는 $102-125 \mu \mathrm{m}$ 이다. 세포 크기는 물론 착편모의 길이에서도 이번 관찰된 
Chrysochromulina속 종들 중에서 가장 큰 종이었다. 물론 지 금까지 알려진 Chrysochromulina속에서도 그 크기가 큰 그룹 에 속하는 것으로 알려져 있다(Eikrem and Moestrup 1998). 착편모는 Chrysochromulina속의 여러 종들에서 보여지는 것처 럼 coiling현상을 나타낸다. 세포가 유영할 때는 긴 착편모를 유영 방향으로 길게 뻗고 길이가 같은 두개의 편모는 착편모 와 반대방향으로 뻗어 유영하며, 어떠한 자극에 대해 순간적 으로 착편모가 코일 모양으로 감겨 그 길이가 매우 짧아지고 유영을 멈춘다. 전자현미경 관찰에 의하면 세포는 두 종류의 인편으로 둘러싸여 있다. 세포 바로 위를 둘러싸고 있는 안 쪽층 인편 (internal scale)은 판상 인편 (plate scale, Fig. 1-B) 으로 그리고 그 바깥쪽 인편 (external scale)은 침상 인편 (spine scale, Figs 1-C, D)으로 둘러싸여 있다(Fig. 1-E). 판 상 인편은 그 크기가 $0.65-0.80 \times 0.45-0.54 \mu \mathrm{m}$ 로 비교적 크 며, 방사상으로 곧게 뻗은 능선이 규칙적으로 나열되어 있으 며, 인편의 가장자리는 편평한 중앙부위와는 달리 다소 불룩 하게 튀어나와 있다. 반면 침상 인편은 비교적 작아서 그 크 기가 $0.21-0.33 \mu \mathrm{m}$ 이며 침 (spine)의 길이는 $0.20-0.35 \mu \mathrm{m}$ 이 다. 인편의 중앙부에 돌출해 나온 침은 4 개의 지주대로 단단 히 고정되어 있다. 침상 인편의 가장자리 또한 판상 인편에 서와 비슷하게 약간 불룩하게 튀어나와 있는데 이 인편의 침 을 지지해주는 4 개 지주대의 끝이 인편의 가장자리까지 뻗어 있다. 침상 인편에서 침이 나 있는 면에는 가는 능선에 의한 동심원 문양을 볼 수 있으나 그 반대면에는 판상 인편의 것 과 유사한 방사상으로 곧게 뻗은 능선을 관찰할 수 있었다 (Figs 1-C, D). 이처럼 이번 연구에서 관찰되어진 세포의 형 태 및 인편의 형태는 Jonsen and Moestrup(1999)의 연구 결 과에서와 동일한 형태를 취하고 있음을 알 수 있었다. C. ahrengotii의 인편의 형태는 C. scutellum의 그것과 유사하다. 그러나 C. scutellum의 경우에는 2가지 형태의 침상 인편을 가지는 점에서 다르다(Eikrem and Moestrup 1998).

\section{Chrysochromulina simplex Estep, Davis, Hargraves et Sieburth (Fig. 2)}

세포는 두개의 편모와 하나의 긴 착편모를 가지며(Fig. 2$\mathrm{A})$, 세포크기는 길이가 2.5-3.2 $\mu \mathrm{m}$, 폭이 2.1-2.9 $\mu \mathrm{m}$ 정도로 Chrysochromulina속 종들 중에서는 비교적 작은종이다. Chrysochromulina속 대부분의 종들에서와 마찬가지로 착편모 는 coiling 현상을 나타낸다. 전자현미경을 이용한 관찰에 의 하면 편모 표면에 원뿔형의 돌기가 나 있다(Figs. 2-B, C). 또한 이 종의 편모의 길이는 보통 같고 다르다 하더라도 3.4 $\mu \mathrm{m}$ 이상의 차이를 나타내지 않는다고 알려져 있으며 (Birkhead and Pienaar 1995) 이번 연구에서 관찰된 모든 개체 들에서도 2 개 편모의 길이는 서로 달라서 긴 편모는 약 10.1 $\mu \mathrm{m}$ 전후, 짧은 편모는 약 $8.9 \mu \mathrm{m}$ 전후로 짧은 편모와 긴 편
모의 길이는 약 $1.2 \mu \mathrm{m}$ 정도의 차이를 나타내었다. 이 종의 착편모의 길이는 세포의 연령에 따라 그 길이가 다양하여 세 포가 분열한 후 12 시간이 되면 $28 \mu \mathrm{m}$ 보다 짧은 길이가 최대 로 성장하였을 때에 $79 \mu \mathrm{m}$ 까지 길어지는 것으로 보고 되었 다(Birkhead and Pienaar 1995). 이 연구에서 착편모에서는 편 모에서 관찰되었던 표면의 돌기는 관찰할 수 없었으며 길이 는 약 57-61 $\mu \mathrm{m}$ 였다. 세포 표면은 한 종류의 판상 인편(plate scale, Figs 2-D-F)으로 덮혀 있었다. 인편은 거의 원형에 가 까운 형태를 하고 있으며, 그 크기는 0.35-0.51 $\mu \mathrm{m}$ 로 21-26 개의 방사상으로 곧게 뻗은 능선이 나 있음을 관찰할 수 있 었다. 또한 인편의 가운데 부분에는 불완전한 십자 모양의 능선이 관찰되는 경우도 있다(Fig. 2-F). 이 종의 인편의 형 태에 관해서는 여러 연구자들의 연구 결과에서 다소의 차이 점을 발견할 수 있었는데, 이들 인편의 형태적 특징의 다양 성에 관해서는 Birkhead and Pienaar(1995)가 정리하였다. 이 들의 정리에 의하면 이번 연구에서 나타난 C. simplex의 인편 은 Birkhead and Pienaar(1995)의 연구에서 나타난 종의 그것 과 매우 유사함을 알 수 있다. 그리고 이들 인편의 반대쪽 면, 즉 세포에 닿는 면에는 일정한 규칙이 없는 동심원의 문 양을 관찰할 수 있었다(Fig. 2-E).

\section{Chrysochromulina spinifera(Fournier) Pienaar et Norris (Fig. 3)}

광학현미경을 이용한 관찰에 의하면 이 종은 Chrysochromulina속 종들에서 일반적으로 보여지는 빠른 유영속도, 착 편모의 coiling 현상은 관찰되지 않았다. 또한, 광학현미경을 이용한 관찰에서는 편모의 길이가 다소 차이가 있음을 정확 히 관찰할 수는 없었으나, 전자현미경을 이용한 관찰 결과에 의하면 2 개의 편모 길이는 다소 차이를 나타내고 있음을 알 수 있다(Fig. 3-B). 즉, 길이가 서로 다른 2개의 편모(각각 약 $22.6 \mu \mathrm{m}, 39.6 \mu \mathrm{m}$ 전후)와 편모 길이보다 다소 짧은 착편 모 $($ 약 $11.7 \mu \mathrm{m}$ 전후 $)$ 가 관찰되며, 이외에 길이가 매우 긴 침 상 인편을 관찰할 수 있었다(Fig. 3-A, B). 편모와 침상 인편 을 제외한 세포의 외형은 말 안장 모양(직경 약 $3.9 \mu \mathrm{m}$ )을 취하고 있다. 이 종은 두가지 형태의 인편을 가진다(Figs. 3C-G). 길이가 비교적 긴 침상 인편(Figs. 3-A, C, D)과 타원 형의 판상 인편(Figs 3-E, G)이 그것이다. 침상 인편(길이 16-22 $\mu \mathrm{m}$, 폭 $0.2 \mu \mathrm{m}$ )은 수많은 가는 섬유상 줄기가 인편의 기부에서 끝부분까지 이어져 있으며(Figs. 3-C, D), 침상 인 편의 맨 끝부분은 4 개의 뾰족한 극처럼 섬유상 줄기부분이 연장되어 돌출되어져 있다(Fig. 3-D). 그 반대편인 기부는 원뿔을 연상시키는 모양을 하고 있다(Fig. 3-C). 하나의 세 포에 이러한 침상 인편이 적게는 9개에서 영양염을 첨가한 배지에서 배양시에는 40개 이상이 관찰된다는 보고(LeRoi and Hallegraeff 2004)가 있으나 이번 연구에서는 하나의 세포 에서 10-31개의 침상 인편이 관찰되었다. 판상 인편(길이 


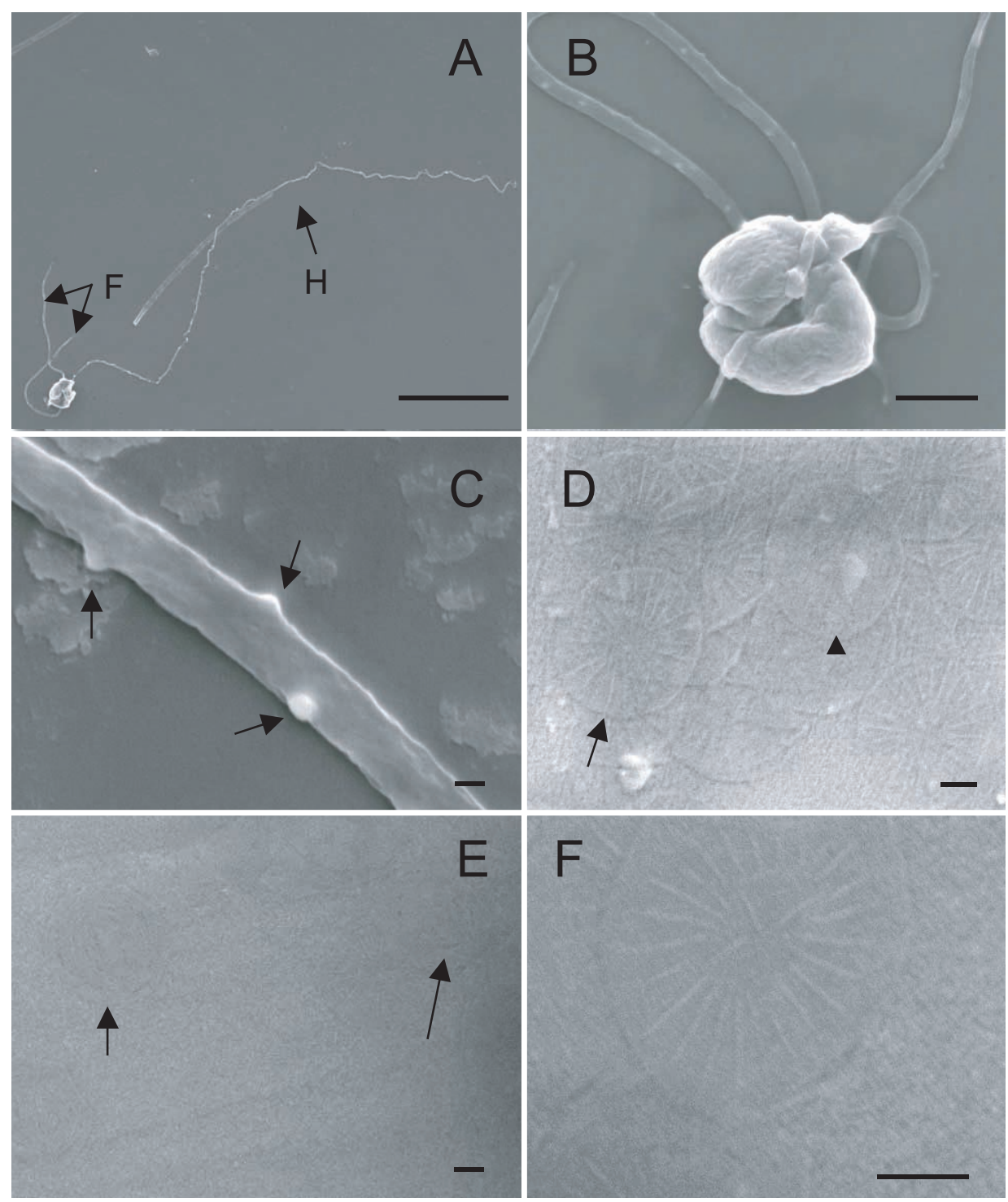

Fig. 2. Chrysochromulina simplex. A. Whole cell with flagella (F) and haptonema (H), B. The flagella, which may be distinguished by the presence of many short spines, C. The fine structure of short spines (arrows) on flagella, D. Distal (arrow) and proximal (arrow head) surface of plate scales, E. Proximal surface of plate scales (arrows), F. The centric area of the scale is raised with an excentric cross on distal surface. Scale bars $=10 \mu \mathrm{m}(\mathrm{A}), 1 \mu \mathrm{m}(\mathrm{B})$ and $0.1 \mu \mathrm{m}(\mathrm{C}-\mathrm{F})$.

0.8-1.0 $\mu \mathrm{m}$, 폭 0.6-0.9 $\mu \mathrm{m})$ 의 표면에는 C. ahrengotii와 C. simplex의 판상 인편에서 관찰되었던 곧게 뻗은 능선 문양과 는 달리 약간 휘어진 능선 문양을 관찰 할 수 있었으며, 이들 능선 문양은 하나의 판상 인편을 4 개의 구획으로 뚜렷하게 나뉘어 보이게 배열되어 있다(Figs. 3-F, G). 그러나 이들 판 상 인편의 반대쪽 면, 즉 세포 표면에 부착하는 면에서는 짧 은 능선이 낙서를 한 듯 불규칙하게 배열되어 있음을 알 수 있었다(Fig. 3-F). C. spinifera 인편의 형태는 얼핏 C. ericina 의 그것과 유사하여 혼돈을 가져올 수 있으나 C. ericina는 C. spinifera의 침상 인편의 특징인 가는 섬유상 줄기와 인편 끝 부분의 4 개의 뾰족한 극부분 등과 같은 특징을 가지지 않는 다(Moestrup 1979). 처음 광학현미경을 이용한 관찰을 통해
얻어진 C. spinifera가 coiling을 하지 않는 착편모를 가지는 특 징으로 인해 새로운 속인 Chrysocampanula spinifera Fournier로 명명되어지기도 했다(Fournier 1971; Moestrup 1979).

\section{Genus Prymnesium}

\section{Prymnesium paroum N. Carter (Fig. 4)}

P. paroum 세포는 장타원형의 쌀알 모양을 하며, 길이는 약 8-10 $\mu \mathrm{m}$ 이며 폭은 5-6 $\mu \mathrm{m}$ 로 그 형태가 P. patelliferum 세 포와 매우 유사하여 광학현미경 관찰로는 두 세포를 구분하 기 힘들다(Moestrup and Larsen 1992; 김과 정 2004c). 또한 두 세포 모두 길이가 거의 동일한 2개의 편모(9.5-12 $\mu \mathrm{m})$ 를 


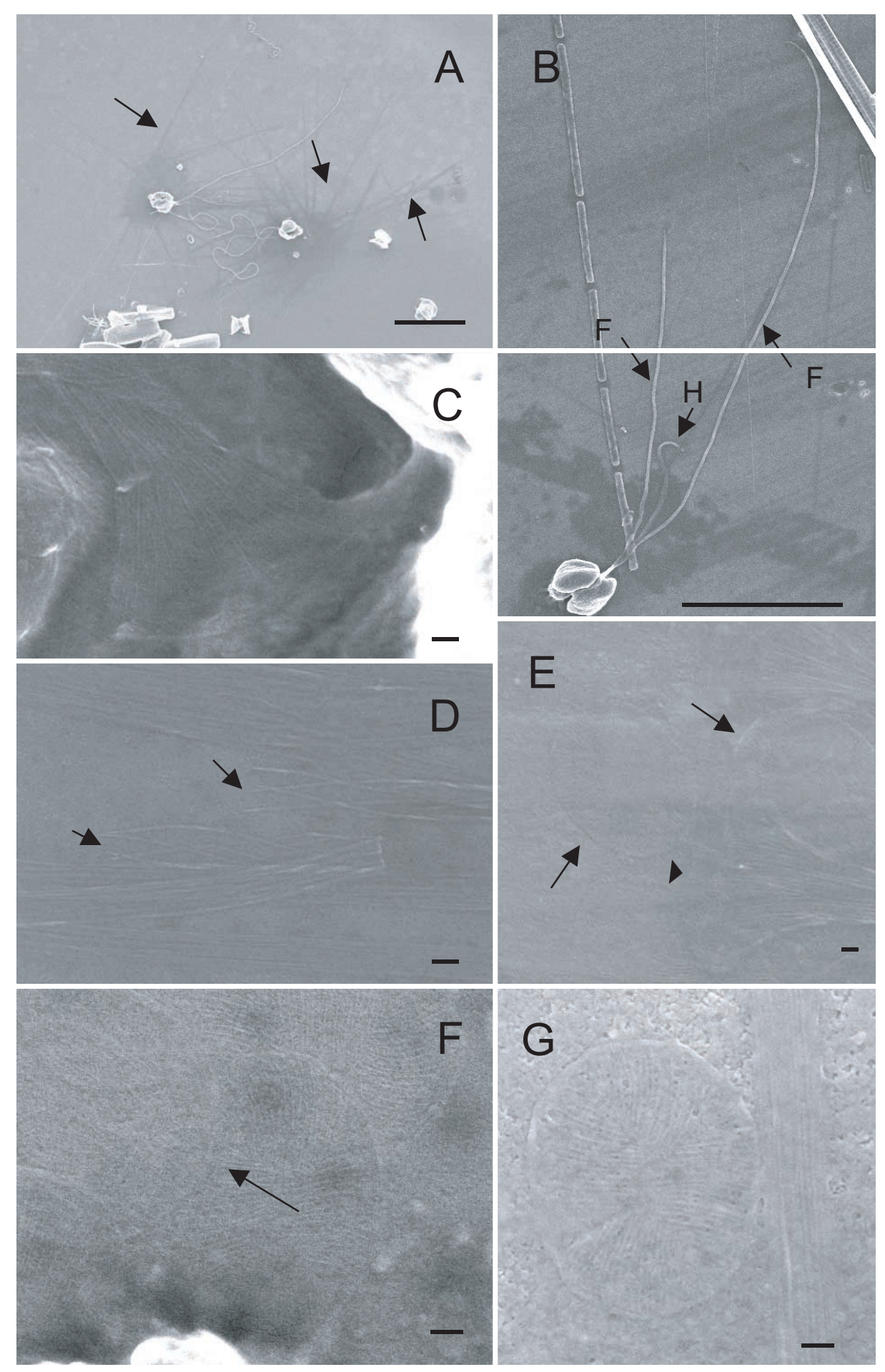

Fig. 3. Chrysochromulina spinifera. A. Whole cell with long spine scales (arrows), B. Non-coiling haptonema (H) and flagella of unequal length (F) of the cell, C. Proximal part of spine scale, D. Tip of spine scale, showing the thorns (arrows), E. Plate scales (arrows) and proximal part of spine scale (arrow head), F. Proximal surface of plate scale (arrow), G. Distal surface of plate scale. Scale bars $=10 \mu \mathrm{m}(\mathrm{A}, \mathrm{B})$ and $0.1 \mu \mathrm{m}(\mathrm{C}-\mathrm{G})$.

가지며 그 편모 사이에 1 개의 착편모(3.0-4.5 $\mu \mathrm{m})$ 가 위치한 다(Fig. 4-A). P. paroum 세포의 표면은 두 종류의 판상 인편 (Figs. 4-B, C)으로 덮혀 있으며, 전자현미경 관찰을 위한 시 료 처리과정에서 인편이 세포 주변에 탈락한 것을 관찰할 수
있다. 세포 바로 위를 둘러싸고 있는 안쪽층 인편 $(0.28-0.30 \times$ $0.30-0.37 \mu \mathrm{m})$ 은 타원형에 가깝고 인편의 중앙부를 중심으 로 가는 능선이 방사상으로 인편 가장자리를 향해 곧게 뻗어 있다(Fig. 4-D). 방사상으로 나 있는 능선은 하나의 인편을 

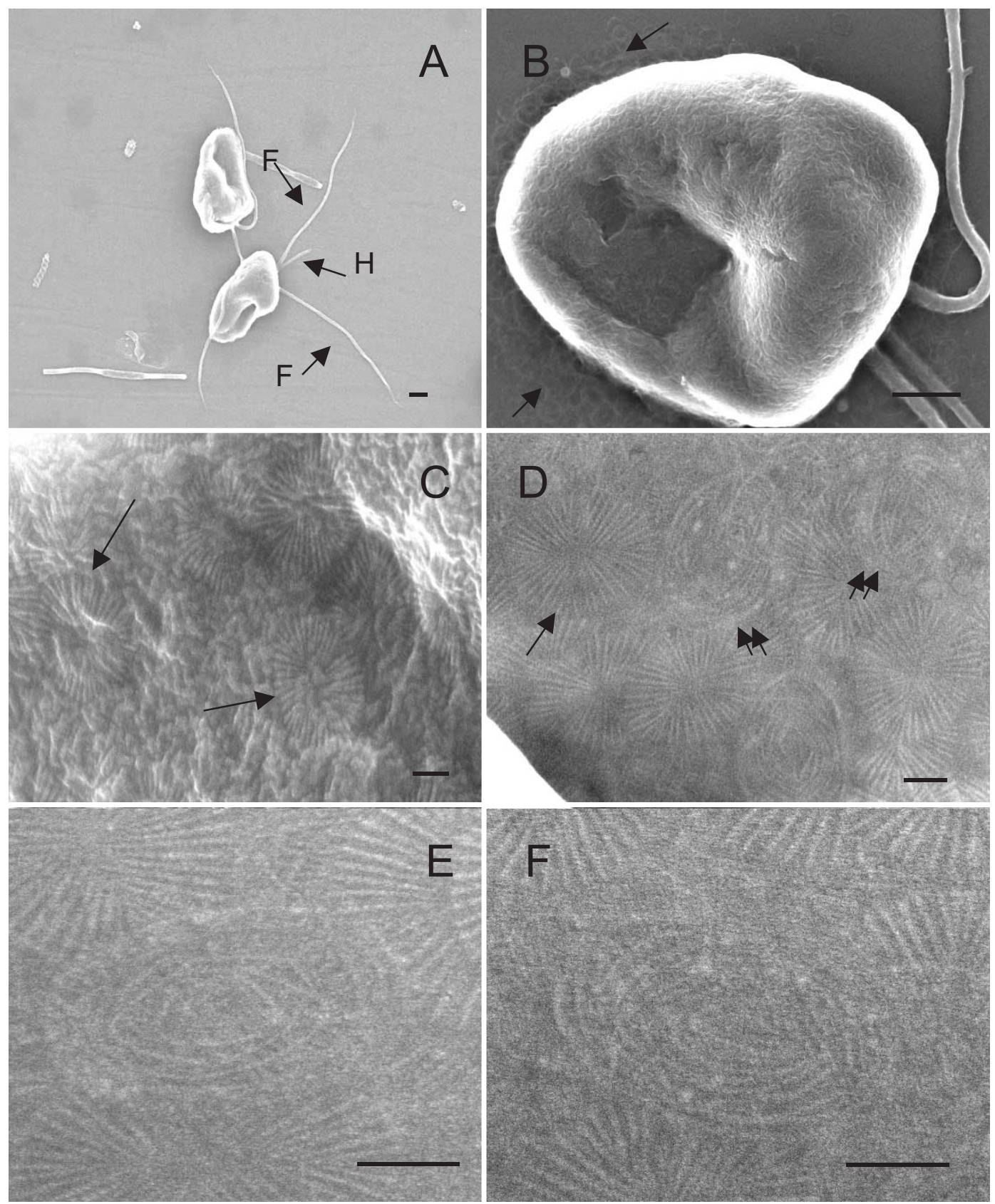

Fig. 4. Prymnesium paroum. A. Whole cell with flagella (F) and haptonema (H), B. Detached scales (arrows), C. Scales attached on the cell surface, D. Internal scale (arrow) and external scales (double arrows), E. The one type of external scale has a wide rim, F. The other type of external scale has a very narrow rim. Scale bars $=1 \mu \mathrm{m}(\mathrm{A}, \mathrm{B})$ and $0.1 \mu \mathrm{m}(\mathrm{C}-\mathrm{F})$.

4 개의 구획으로 나뉘어 보이게 배열되어 있으며, 한 구획에 약 11-12개의 능선이 위치한다. 이러한 인편의 형태는 $P$. patelliferum 세포의 안쪽층 인편과 거의 형태적 측면에서 차이 가 없다(김과 정 2004c). 세포의 바깥층 인편 $(0.19-0.20 \times$ 0.33-0.37 $\mu \mathrm{m})$ 은 안쪽층 인편과 그 모양이 현저히 다르다. 즉, 인편 표면의 능선이 일정한 규칙 없이 동심원을 그리며 인편의 가장자리는 테두리(rim)가 비교적 위쪽으로 돌출되 어 경계를 확실히 보여주고 있다(Figs. 4-D-F). 또한 이들 테 두리의 폭이 넓은 인편(Fig. $4-\mathrm{E})$ 과 비교적 좁은 인편(Fig.
4-F) 등 두 종류의 인편으로 구성되어 있다. 이처럼 Prymnesium속의 여러 종의 경우 세포의 가장 바깥층을 둘러 싸고 있는 인편의 형태적 특징들이 종 동정시 중요한 분류키 로서 이용되어진다. 그 형태도 다양해서 바구니 모양의 인편 (P. calathiferum; Chang and Ryan 1985), 기본적으로 안쪽층 인편과 같은 문양의 인편 표면에 6 개의 선이 그어져 있는 인 편 (P. zebrinum; Billard 1983) 그리고 타원형의 크고 작은 2개 의 고리가 포개져 있는 모양의 인편(P. annuliferum; Billard 1983) 등 매우 다양하다. 


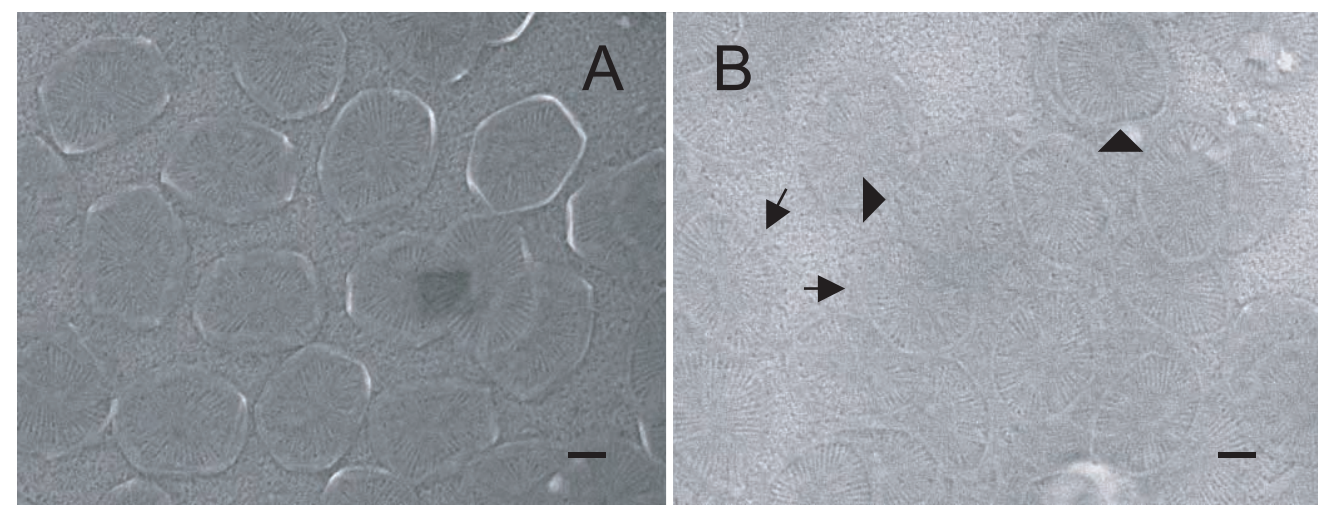

Fig. 5. Prymnesium patelliferum. A. External scales with relatively tall upright rims B. Internal scales (arrows) and external scales (arrow heads). Scale bars $=0.1 \mu \mathrm{m}$.

\section{Prymnesium patelliferum Green, Hibberd and Pienaar (Fig. 5)}

광학현미경 관찰에 의하면 P. paroum 세포와 구분이 불가 능할 정도로 유사한 세포형태를 취한다. 세포의 표면은 $P$. paroum 세포에서와 같이 두 종류의 판상 인편 $(0.20-0.25 \times$ 0.22-0.28 $\mu \mathrm{m}$ )으로 덮혀 있다(Figs. 5-A, B). 전술한 바와 같 이 세포표면을 덮고 있는 판상 인편 중 가장 안쪽층 인편 (Fig. 5-B)은 그 모양이 P. paroum 세포의 그것과 매우 유사 하다. 반면 P. paroum 세포와 구분되어지는 종 특성은 세포 의 바깥층 인편 $(0.25-0.23 \times 0.30-0.35 \mu \mathrm{m})$ 의 모양이 확실히 다르다는 점이다(Fig. 5-A). P. patelliferum의 바깥층 인편은 안쪽층 인편과 모든 점에서 유사하나, 인편 가장자리를 확실 하게 구분 지을 수 있는 테두리가 비교적 위쪽으로 돌출되어 있는 점 (tall upright rim)에서 차이를 보인다(김과 정 2004c).

\section{Division PRASINOPHYTA \\ Class Prasinophyceae \\ Order Mamiellales \\ Family Mamiellaceae \\ Genus Mamiella}

\section{Mamiella gilva Moestrup (= Nephroselmis gilva) (Fig. 6)}

세포는 거의 구형 (5-6 $\mu \mathrm{m})$ 에 가까우며 2개의 편모(40-63 $\mu \mathrm{m}$ )를 가진다(Fig. 6-A). 편모에는 광학현미경으로는 전혀 관찰할 수 없는 소수의 가는 측사(flagellar hair, 3.2-3.8 $\mu \mathrm{m}$, Fig. 6-B)가 나 있으며 전자현미경 관찰을 통해 확인할 수 있 다. 특히 이 생물 종은 세포 표면 이외에 편모의 표면에도 인 편 $(0.10-0.15 \times 0.24-0.27 \mu \mathrm{m}$, Figs. $6-\mathrm{C}, \mathrm{D})$ 이 존재한다. 편 모를 덮고 있는 인편은 타원형에 가깝고 능선은 거미줄 모양 을 나타내며 가운데 부분에서 침 (spine, 약 $0.15 \mu \mathrm{m}$ )이 날카 롭게 돌출되어 있다(Fig. 6-D). Moestrup(1984)은 편모를 덮 고 있는 인편은 편모를 따라 줄을 지어 나란히 배열되어 있
으며 더욱이 인편의 중앙부로부터 돌출되어 있는 날카로운 침은 마치 줄무늬처럼 보여진다고 서술하였다. 이에 반해 세 포 표면을 덮고 있는 인편 $(0.25-0.28 \mu \mathrm{m})$ 은 침이 없는 편평 한 판상 인편으로 편모를 덮고 있는 인편에서와 같이 능선이 거미줄 모양을 나타내지만 인편의 전체적인 모양은 거의 팔 각형으로 되어 있어 편모를 덮고 있는 인편과는 구분된다 (Figs. 6-E, F).

\section{Division CHROMOPHYTA \\ Class Chrysophyceae \\ Order Ochromonadales \\ Family Paraphysomonadaceae \\ Genus Paraphysomonas}

\section{Paraphysomonas imperforata Lucas (Fig. 7)}

세포는 구형 $(3.0-3.3 \mu \mathrm{m})$ 이며 길이가 서로 다른 두개의 편 모를 갖는다. 긴 편모는 9.5-13.0 $\mu \mathrm{m}$ 로 많은 측사(1.0-1.7 $\mu \mathrm{m}$, Fig. $7-\mathrm{A})$ 를 가지며, 짧은 편모는 긴 편모에서 관찰되는 측사가 없어 매끈하고 그 길이는 2.0-4.5 $\mu \mathrm{m}$ 정도이다. 세포 는 한 종류의 인편(Figs. 7-A, B)으로 둘러싸여 있다. 인편은 직경이 약 $0.8 \mu \mathrm{m}$ 인 원형으로 이루어지며 원형의 인편 가운 데로부터 침(spine)이 나 있다. 침의 끝은 매우 날카롭고 그 길이는 약 $0.62-0.7 \mu \mathrm{m}$ 이다(Fig. $7-\mathrm{B})$. 다음에 설명하게 될 $P a$. vestita와는 달리 인편의 가장자리가 발달하지 않아서 확 실한 인편 테두리가 관찰되지 않는다(Fig. 7-B). 이 종은 해 양은 물론 담수에서도 그 서식이 보고 되었으며 그 형태적 변이도 매우 다양한 것으로 알려져 있다(Preisig and Hibberd 1982; 이 등 1995a; Lim et al. 2001). 특히 Pa. butcheri, Pa. imperforata, $\mathrm{Pa}$. vestita는 담수와 해수 모두에서 출현하고 그 외의 Paraphysomonas속의 종들은 담수종 또는 해수종으로 그 서식 수역이 확실히 구분되어진다(이 등 1995a). 전술한 Chrysochromulina속과 Prymnesium속을 포함하는 5종의 

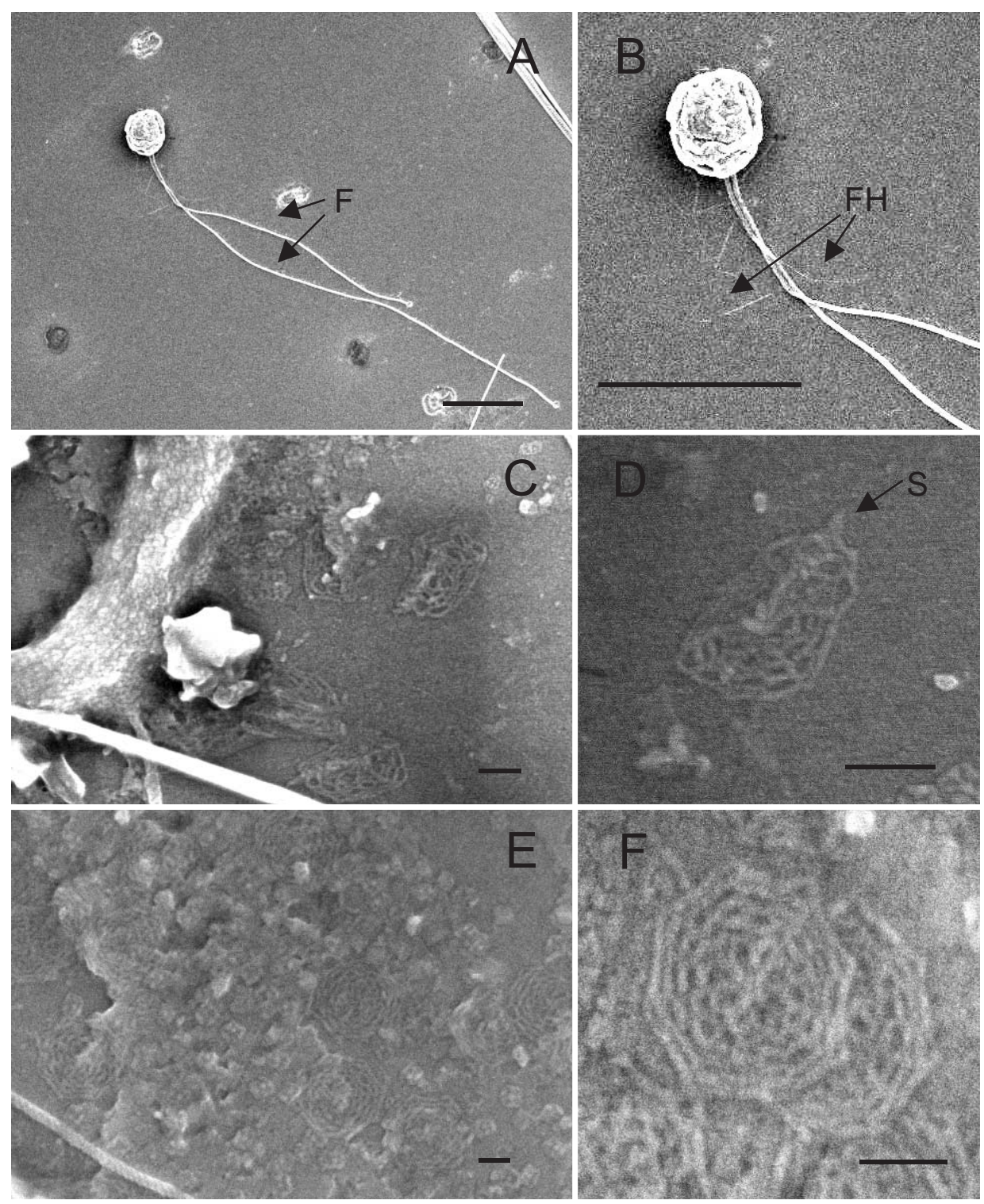

Fig. 6. Mamiella gilva. A. Whole cell with flagella of unequal length (F), B. Flagella have very short and thin flagella hairs (F H), C. Detached scales from flagella, D. The flagella scale, which may be distinguished by presence of a spine (S), E. Detached scales from the cell body, F. The body scale is plate-like of a spider's web pattern. Scale bars $=10 \mu \mathrm{m}(\mathrm{A}, \mathrm{B})$ and $0.1 \mu \mathrm{m}(\mathrm{C}-\mathrm{F})$.

Haptophyta와 Prasinophyta인 M. gilva의 인편은 유기질 성 분인 반면 이 연구에서 관찰된 Paraphysomonas속의 두 종의 인편은 규산질로 이루어져 있다(Wujek and O'Kelly 1992; 이 등 1995a; Tomas 1997).

\section{Paraphysomonas vestita (Stokes) de Saedeleer (Fig. 7)}

세포는 구형이며 직경이 5-12 $\mu \mathrm{m}$ 이다. Pa. imperforata에서 와 같이 길이가 다른 두개의 편모를 가진다. 긴편모는 17-42 $\mu \mathrm{m}$ 이며 수 많은 측사 $(1.5-2.3 \mu \mathrm{m})$ 를 가진다. 이와 달리 짧 은 편모는 4-6 $\mu \mathrm{m}$ 로 측사를 가지지 않고 매끈하다. 세포는 원형의 인편(1.2-1.4 $\mu \mathrm{m})$ 으로 둘러싸여 있으며 인편 가운데 로부터 침(spine)이 나있으며, 그 길이가 $\mathrm{Pa}$. imperforata보다
길어서 4.3-5.5 $\mu \mathrm{m}$ 에 달한다(Fig. 7-C). 또한 전술한 $\mathrm{Pa}$. imperforata와는 달리 인편 테두리가 볼록하게 튀어나와 인편 의 경계선을 확실하게 보여준다(Wujek and O'Kelly 1992; 이 등 1995a, Fig. 7-D).

전술한 바와 같이 해양 생태계내에서 중요한 역할을 담당 하고 있는 미소 편모조류들 중 인편을 가지는 미소 편모조류 8 종을 전자현미경을 이용하여 인편의 형태를 중심으로한 세 포 형태를 관찰하였다. 미소 편모조류는 세포 크기가 매우 작아서 아직까지 채집, 관찰 및 배양 방법 등의 연구 방법이 체계화 되어있지 않음으로 인해 그 중요성에 비추어 많은 연 구가 이루어지지 않았던 것이 사실이다. 또한, 지금까지 우 리나라에서 보고된 Paraphysomonas屬이 담수산임을 감안한다 

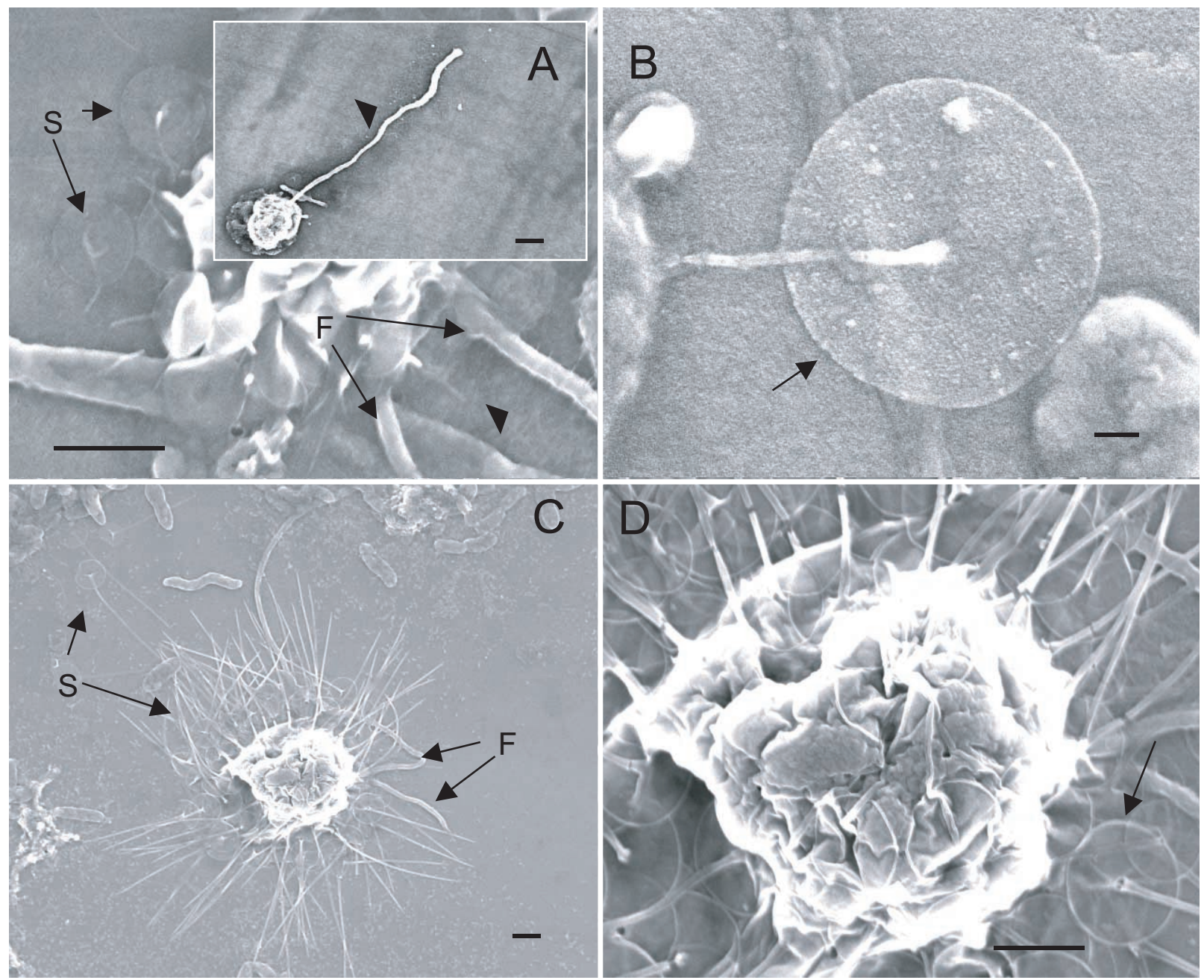

Fig. 7. Paraphysomonas imperforata (A and B) and Pa. vestita (C and D). A. Cell with flagella (F) and spine scales (S), The flagellum have very short and thin hairs (arrow heads), B. A scale without a thickened rim (arrow), C. Whole cell with flagella of unequal length (F) and scales (S), D. Detached scales with a slightly thickened rim (arrow). Scale bars $=1 \mu \mathrm{m}$ (A, C and D) and $0.1 \mu \mathrm{m}$ (B).

면 P. patelliferum을 제외한 모든 종들이 우리나라의 해역에 서는 처음으로 보고되는 종들이다. 이들 종 중에는 $P$. paroum과 P. patelliferum 등 두 종이 독성을 가지며(Igarashi et al. 1993, 1996; Meldahl et al. 1994; Koski et al. 1999; Granéli and Johansson 2003; 김과 정 2005) 연안 해역에 서식하는 생 물에 나쁜 영향을 미칠 수 있으므로 이번 연구를 기초로 분 류는 물론 배양과 독성 연구 등 다양한 각도에서의 미소 편 모조류에 대한 연구가 이루어져야할 것으로 판단된다.

\section{사 사}

이 논문은 2002년도 한국학술진흥재단의 지원에 의해 연 구 되었으며 이에 감사드립니다. (KRF-2002-075-C00021)

\section{참고문헌}

김형신, 정민민. 2004a. 한국 연안해역의 착편모조 분포. 한국양식학회 지 17: 133-138.

김형신, 정민민. 2004b. 제주 연안의 착편모조. 제주대학교 기초과학연 구소 논문집 17: 159-164.

김형신, 정민민. 2004c. Prymnesium patelliferum Green, Hibberd and Pienaar (Haptophyta)의 형태 특성 고찰. 한국조류학회지 19: 277282.

김형신, 정민민. 2005. 해산 요각류 Tigriopus japonicus 개체군 성장에 미 치는 착편모조의 영향. 한국양식학회지 18: 86-91.

이상명, 이호원, 이갑숙, 고각영치. 1995a. 한국산 인편성황갈조 식물에 대한 연구(VI): 7개 댐 Paraphysomonas屬의 식물상. 한국조류학회 지 10:15-28.

이상명, 이호원, 이갑숙, 고각영치, 강현무. 1995b. 한국산 인편성황갈 조식물에 대한 연구(V): 7개 댐 Chrysosphaerella屬과 Spiniferomonas 屬의 식물상. 한국육수학회지 28: 159-174.

Billard C. 1983. Prymnesium zebrinum sp. nov. et $P$. annuliferum 
sp. nov., deux nouvelles espèces apparentées à $P$. parvum Carter (Prymnesiophyceae). Phycologia 22: 141-151.

Birkhead M. and Pienaar R.N. 1995. The taxonomy and ultrastructure of Chrysochromulina simplex (Prymnesiophyceae). Phycologia 34: 145-156.

Chang F.H. and Ryan K.G. 1985. Prymnesium calathiferum sp. nov. (Prymnesiophyceae), a new species isolated from Northland, New Zealand. Phycologia 24: 191-198.

Eikrem W. and Moestrup Ø. 1998. Structural analysis of the flagellar apparatus and the scaly periplast in Chrysochromulina scutellum sp. nov. (Prymnesiophyceae, Haptophyta) from the Skagerrak and the Baltic. Phycologia 37: 132-153.

Fournier R.O. 1971. Chrysochromulina spinifera gen. et. sp. nov., a new marine haptophyte from the Bay of Chaleurs, Quebec. Phycologia 10: 89-92.

Granéli E. and Johansson N. 2003. Increase in the production of allelopathic substances by Prymnesium parvum cells grown under N- or P-deficient conditions. Harmful Algae 2: 135145.

Hallegraeff G.M. 1981. Seasonal study of phytoplankton pigments and species at a coastal station off Sydney: importance of diatoms and nanoplankton. Mar. Biol. 61: 107-118.

Igarashi T., Satake M. and Yasumoto T. 1996. A potent ichthyotoxin and hemolytic glycoside isolated from the red tide algae Prymnesium parvum. J. Am. Chem. Soc. 118: 479480.

Igarashi T., Oshima Y. Murata M. and Yasumoto T. 1993. Chemical studies on prymnesins isolated from Prymnesium parvum. In: P. Lassus, G. Arzul, E. Erard, P. Gentien and C. Marcaillou (eds), Harmful Marine Algal Blooms. Proceedings of the Sixth International Conference on Toxic Marine Phytoplankton. pp. 303-308.

Jensen M.Ø. and Moestrup Ø. 1999. Ultrastructure of Chrysochromulina ahrengotii sp. nov. (Prymnesiophyceae), a new saddle-shaped species of Chrysochromulina from Danish coastal waters. Phycologia 38: 195-207.

Koski M., Rosenberg M. Vittasalo M. Tanskanen S. and Sjölund U. 1999. Is Prymnesium patelliferum toxic for copepod?Grazing, egg production and egestion of the calanoid copepod Eurytemora affinis in mixtures of "good" and "bad" food. J. Mar. Sci. 56: 131-139.

Lee S.M., Lee H.W., Lee K.S. and Takahashi E. 1994. Studies on Scale-bearing Chrysophyta from Korea(IV): Taxonomic studies on Chrysodidymus. Kor. J. Limnol. 27: 377-381.

LeRoi J.M. and Hallegraeff G. 2004. Scale-bearing nanoflagellates from southern Tasmanian coastal waters, Australia. I. Species of the genus Chrysochromulina (Haptophyta). Bot. Mar. 47: 73-102.

Lim E.L., Dennett M.R. and Caron D.A. 2001. Identification of heterotrophic nanoflagellates by restriction fragment length polymorphism analysis of small subunit ribosomal DNA. J. Eukaryot. Microbiol. 48: 247-257.

Malone T.C. 1980. Algae size. In: I. Morris (ed), The physiological ecology of phytoplankton. Blackwell Scientific Publication, Oxford. pp. 433-463.

Meldahl A.S., Edvardson B. and Fonnum F. 1994. Toxicity of four potentially ichthyotoxic marine phytoflagellates determined by four different test methods. J. Toxicol. and Environ. Health 42: 289-301.

Moestrup Ø. 1979. Identification by electron microscopy of marine nanoplankton from New Zealand, including the description of four new species. N. Z. J. Bot. 17: 61-95.

Moestrup Ø. 1984. Further studies on Nephroselmis and its allies (Prasinophyceae). II. Mamiella gen.nov., Mamiellaceae fam. nov., Mamiellales ord.nov.. Nord. J. Bot. 4: 109-121.

Moestrup, Ø. 1994. Economic aspects: 'blooms', nuisance species and toxins. In: J.C. Green and B.S.C. Leadbeater (eds), The Haptophyte Algae. The Systematics Association. pp. 265-285.

Moestrup Ø. and Larsen J. 1992. Potentially Toxic Phytoplankton. 1. Haptophyceae (Prymnesiophyceae). ICES Identification Leaflets for Plankton. Denmark. 11 pp.

Preisig H.R. and Hibberd D.J. 1982. Ultrastructure and taxonomy of Paraphysomonas (Chrysophyceae) and related genera 1. Nord. J. Bot. 2: 397-420.

Tomas C.R. 1997. Identifying marine phytoplankton. Academic Press. 858pp.

UNESCO. 2003. IOC Taxonomic Reference List of Toxic Plankton Algae, IOC, UNESCO, pp. 49.

Wujek D.E. and O'Kelly C.J. 1992. Silica-scaled Chrysophyceae (Mallomonadaceae and Paraphysomonadaceae) from New Zealand freshwaters. N. Z. J. Bot. 30: 405-414.

Received 10 October 2005

Accepted 15 November 2005 